\title{
KUALITAS MIKROBIOLOGIS SILASE DENGAN BERBAGAI KOMBINASI KULIT BUAH SERTA JERAMI JAGUNG (Zea mays L.) DAN LEVEL TEPUNG JAGUNG YANG BERBEDA
}

\author{
A.E. HARAHAP ${ }^{1}$, R. FEBRIYANTI ${ }^{1}$ DAN K. HALIDASIAH ${ }^{2}$ \\ ${ }^{1}$ Fakultas Pertanian dan Peternakan Universitas Islam Negeri Sultan Syarif Kasim Riau \\ ${ }^{2}$ Alumni Fakultas Pertanian dan Peternakan Universitas Islam Negeri Sultan Syarif Kasim Riau \\ Kampus Raja Ali Haji Jl. H.R. Soebrantas KM. 15 Pekanbaru \\ Email :neniannisaharahap@yahoo.co.id
}

\begin{abstract}
The aim of this research is to study of $\mathrm{pH}$, population and to determine the diameter of clear zone lactic bacteria on Escherchia coli isolasted form corn waste silage with addition of different corn flour. The design used completely randomized of factorial using $3 \times 3$. Factor $A$ was the composition of substrate that is : A1:100\% corn feel $+0 \%$ corn straw, A2 : 50\% corn feel $+50 \%$ corn straw, A3:\% corn feel $+100 \%$ corn straw. Factor B was the addition of corn flour, namely : B1: 0\%, $B 2: 5 \%$ and $B 3: 10 \%$. The results showed the not interaction $(P>0.05)$ between factor material used for $p H$ decrease, lactic acid bacteria population and the clear zone diameter on Escherchia coli. The conclusion that silage with addition of corn straw $100 \%$ is the best treatment because it can reduce $p H$, increase the number of BAL population and the diameter of the clear zone.
\end{abstract}

Keywords : Clear zone diameter, corn straw, lactic acid bacteria

\section{PENDAHULUAN}

Ketersediaan pakan masih menjadi kendala pengembangan ternak ruminansia di Indonesia. Hal ini disebabkan sebagian besar bahan pakan bersifat musiman, terkonsentrasi di suatu wilayah dan tidak tepatnya manajemen pengelolaan pakan yang diterapkan selama ini. Hasil samping tanaman jagung merupakan sumber bahan baku yang cukup tersedia sepanjang tahun. Dilihat dari produksi jagung di Provinsi Riau pada tahun 2015 sebesar 30,870 berat kering atau meningkat sebesar 2.219 ton atau 7,74\% dibanding 2014 (BPS Riau, 2015). Peningkatan produksi jagung disebabkan karena meningkatnya luas panen jagung sebesar 368 hektar atau naik $3,05 \%$ disertai dengan meningkatnya produktivitas jagung sebesar 1,09 kuintal per hektar atau naik 4,59\% dibandingkan dengan tahun sebelumnya. Berdasarkan musim panen tahun 2015, luas panen jagung meningkat secara absolut pada bulan September-Desember sebesar 2,334 hektar atau naik sebesar 85,90\% dibandingkan dengan luas panen pada periode yang sama tahun sebelumnya (year on year). Penggunaan limbah tanaman jagung sebagai pakan dalam bentuk segar adalah yang termudah dan termurah tetapi pada saat panen hasil limbah tanaman jagung ini cukup melimpah maka sebaiknya disimpan untuk stok pakan pada saat musim kemarau panjang atau saat kekurangan pakan hijauan. Beberapa teknik pengolahan limbah jagung yang telah dikenal diantaranya yaitu diolah menjadi silase, dimana silase merupakan awetan basah segar yang disimpan dalam silo, sebuah tempat yang tertutup rapat dan kedap udara, pada kondisi anaerob. Pada suasana anaerob tersebut akan mempercepat pertumbuhan bakteri anaerob untuk membentuk asam laktat (Mugiawati, 2013).

Jagung merupakan bahan yang paling ideal untuk ensilase karena mengandung karbohidrat mudah larut yang cukup untuk mendukung fermentasi yang baik dibanding hijauan lainnya. Jagung dapat menyediakan karbohidrat fermentasi karena merupakan sumber Non Fiber Carbohydrate (NFC) yang dapat digunakan 
sebagai bahan tambahan hijauan dalam proses ensilase sehingga dapat mempercepat penurunan $\mathrm{pH}$ selama fermentasi (Sibanda et al., 1997; Yang et al., 2004). Selain itu ketersediaan karbohidrat pada jagung akibat panas yang ditimbulkan selama proses ensilase dapat meningkatkan pertumbuhan bakteri asam laktat selama fermentasi (Theurer et al., 1999). Tepung jagung berpotensial untuk dapat dijadikan aditif sebagai sumber karbohidrat larut air atau Water Soluble Carbohydrate (WSC) karena mengandung BETN yang tinggi yaitu $81,37 \%$ yang mencerminkan karbohidrat larut air (WSC) dalam jumlah besar yang terkandung didalamnya (McDonald et al., 1991). Sumber karbohidrat larut air (WSC) yang banyak akan memberikan asupan makanan bagi bakteri asam laktat sehingga bakteri asam laktat mampu tumbuh dengan jumlah yang banyak sehingga akan berdampak kepada penurunan $\mathrm{pH}$. Berdasarkan penelitian Umam dkk. (2014) menyatakan bahwa penambahan tepung jagung sebagai sumber karbohidrat larut air (WSC) dengan tingkat $0-8 \%$ dalam pembuatan silase rumput gajah berpengaruh terhadap

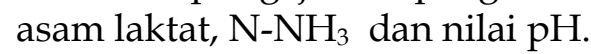

Menurut Chelule dkk. (2010) menyatakan bahwa penggunaan bakteri asam laktat dalam proses fermentasi dapat meningkatkan palatabilitas makanan dan meningkatkan kualitas makanan yaitu peningkatan ketersediaan protein dan vitamin. Semakin lama waktu yang digunakan, semakin tinggi kadar protein terlarut dari tepung yang dihasilkan. Semakin lama fermentasi, asam laktat yang dihasilkan semakin banyak, namun apabila terlalu lama akan mempengaruhi rasa dan aroma tepung yang dihasilkan.

Hasil penelitian Lendrawati dkk. (2012) menunjukkan bahwa data jumlah koloni bakteri asam laktat sebelum ensilase pada perlakuan silase ransum komplit jagung adalah 6,7 x 107. Hal ini menunjukkan bahwa populasi bakteri asam laktat yang terdapat pada silase ransum komplit jagung melebihi batasan minimal (>105 cfu/g) untuk mendukung terjadinya proses fermentasi yang baik (McDonald et al. 1991; Bucmaster 1992) sehingga tidak diperlukan tambahan inokulan bakteri asam laktat dari luar. Selain itu, jumlah koloni bakteri asam laktat isolat jagung lebih tinggi dibandingkan dengan jumlah koloni bakteri asam laktat isolat sawit dan isolat ubi kayu. Jumlah koloni bakteri asam laktat pada silase ransum komplit jagung (SRKJ) ternyata lebih tinggi dibandingkan silase ransum komplit sawit (SRKS) dan ubi kayu (SRKU) (9,2 x $10^{5}$ vs $8,5 \times 10^{4}$ dan $8,0 \times 10^{4} \mathrm{cfu} / \mathrm{g}$ ). Kemudian dari $\mathrm{pH}$ ransum komplit berbasis samping jagung, setelah 6 minggu ensilase adalah 3,80. Nilai ini menunjukkan bahwa silase ransum komplit mempunyai kualitas fermentasi yang baik sekali (ditandai dengan $\mathrm{pH}<4$ ) (Macaulay, 2004). Tujuan penelitian untuk mengetahui $\mathrm{pH}$, populasi serta zona bening BAL terhadap E. coli dan yang diisolasi dari silase kulit buah dan jerami jagung dengan penambahan tepung jagung yang berbeda.

\section{MATERI DAN METODE}

Penelitian ini telah dilaksanakan selama 2 bulan (Maret-April 2017) di Laboratorium Patologi Entomologi dan Mikrobiologi Fakultas Pertanian dan Peternakan Universitas Islam Negeri Sultan Syarif Kasim Riau.

Bahan yang digunakan untuk pembuatan silase yaitu limbah kulit buah jagung, jerami jagung yang diperoleh dari petani yang ada di daerah Kartama, serta tepung jagung komersil yang diperoleh dari pasar yang ada di Pekanbaru. Bahan yang digunakan untuk analisa mikrobiologis adalah cairan silase limbah jagung, media de Man Rogosa Sharpe Agar (MRSA), Nutrien Agar (NA), $\mathrm{NaCl}$ 0,85\%, akuades, E. coli sebagai bakteri uji.

Alat yang digunakan untuk pembuatan silase adalah, silo atau plastik, 
timbangan, pisau, ember, alat tulis, terpal, dan kertas label. Alat yang digunakan untuk analisa mikrobiologis adalah inkubator, hot plate stirrer, colony counter, mikropipet dan blue tip, pipet ukur, jarum inokulum, pipet filler, laminar air flow, cawan petri, $\mathrm{pH}$ meter, bunsen, kapas, tabung reaksi, rak tabung reaksi, plastik, timbangan analitik, aluminium foil, gelas ukur, gelas beaker, gelas erlenmayer, vortex, sarung tangan, autoclave dan jangka sorong/penggaris.

Penelitian ini dilakukan dengan menggunakan Rancangan Acak Lengkap (RAL) pola faktorial dengan $3 \times 3$ perlakuan 3 ulangan untuk setiap perlakuan. Perlakuan yang diberikan adalah sebagai berikut:

Faktor A: Jenis Bahan

$\mathrm{A}_{1}$ 100\% Kulit Buah Jagung + 0\% Jerami Jagung

$\mathrm{A}_{2} \quad 50 \%$ Kulit Buah Jagung $+50 \%$ Jerami Jagung

$A_{3} \quad 0 \%$ Kulit Buah Jagung $+100 \%$ Jerami Jagung

Faktor B: Penambahan Tepung Jagung

$\mathrm{B}_{1}$ 0\% Tanpa Tepung Jagung

$\mathrm{B}_{2}$ 5\% Tepung Jagung

$\mathrm{B}_{3}$ 10\% Tepung Jagung

Semua perlakuan dilakukan fermentasi selama 21 hari.

\section{Peubah yang diukur}

Peubah yang diukur pada penelitian ini adalah :

1. Penentuan $\mathrm{pH}$ (Sudarmadji, 1997).

Pengukuran $\mathrm{pH}$ dilakukan dengan menggunakan $\mathrm{pH}$ meter. Lalu diambil larutan silase limbah jagung dengan penambahan tepung jagung. Dilakukan pengukuran $\mathrm{pH}$ yang hasilnya akan langsung diketahui dengan membaca angka yang ditunjukkan oleh alat.
2. Jumlah Bakteri Asam Laktat (BAL) silase $(\mathrm{cfu} / \mathrm{ml})$

Jumlah koloni BAL pada limbah berbasis jagung diukur menggunakan metode Standard Total Plate Count (TPC) (Cappucino and Sherman, 2005). Berdasarkan kriteria jumlah koloni yang dapat dihitung 30-300 per cawan petri (Dwidjoseputro, 2005).

\section{Pengukuran Diameter Zona Bening}

Pengukuran diameter zona bening BAL terhadap E. coli diukur menggunakan metode difusi sumur yang telah dimodifikasi. Sebanyak 1 ose BAL yang berasal dari kultur stock dan telah diketahui populasinya ditumbuhkan pada media de Man Rogosa Sharpe Broth (MRSB) menurut metode Cintas et al. (1995).

\section{Prosedur Penelitian}

\section{Pembuatan Silase}

Limbah jagung terlebih dahulu dipotong 3-5 $\mathrm{cm}$ dengan menggunakan alat pemotong, selanjutnya semua bahan yang sudah ditimbang sesuai kebutuhannya, limbah jagung dicampur dengan tepung jagung kemudian dimasukkan kedalam kantong plastik hitam dan dipadatkan sehingga mencapai keadaan anaerob, kemudian diikat dan dilapisi dengan plastik kedua selanjutnya plastik tersebut dimasukkan lagi kedalam plastik ketiga, kemudian diikat dan dilakukan fermentasi selama 21 hari.

\section{Isolasi Bakteri Asam Laktat}

Bakteri asam laktat yang digunakan berasal dari cairan silase. Cairan silase ini diperoleh dengan cara memblender silase dengan penambahan akuades melalui perbandingan 1:2. Seperti dapat dilihat pada Gambar 1. 


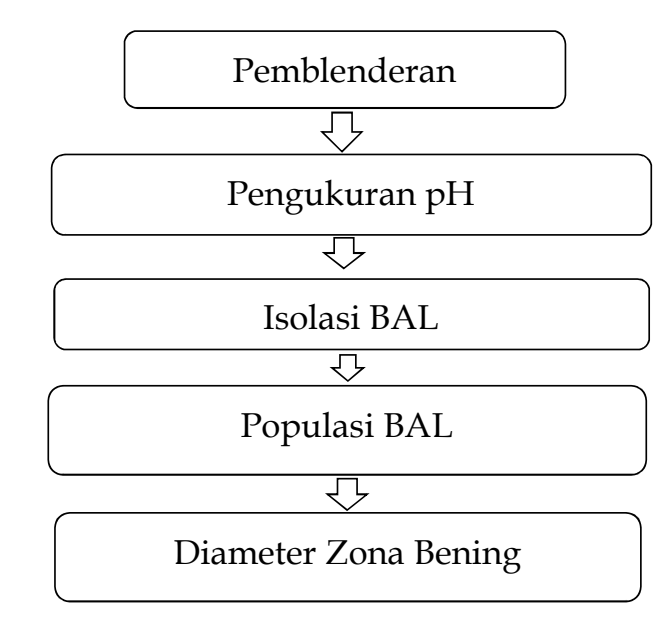

Gambar 1. Tahapan Analisis Mikrobiologis

Selanjutnya penjelasan lebih spesifik dapat dilihat dibawah ini.

\section{Jumlah Bakteri Asam Laktat (BAL) silase $(c f u / m l)$}

Setelah cairan silase diperoleh, selanjutnya adalah penentuan jumlah koloni BAL masing-masing isolat cairan silase menggunakan metode Standard Total Plate Count (TPC) (Cappucino and Sherman, 2005). Sebanyak $1 \mathrm{ml}$ isolat cairan silase dimasukkan ke dalam $9 \mathrm{ml}$ $\mathrm{NaCl}$ fisiologis 0,85\%, lalu diencerkan sampai pengenceran 6 kali secara serial. Sebanyak $1 \mathrm{ml}$ dari pengenceran 5 dan 6 kali ditanam pada cawan petri berisi media de Man Rogosa Sharpe Agar (MRSA). Selanjutnya Media agar diinkubasi pada suhu ruang selama 2 hari. Koloni yang tumbuh berbentuk bulat miring bewarna agak kekuningan. Kemudian populasi BAL di hitung sebagai berikut:

Populasi BAL (cfu/ml)

$=$ Jumlah Koloni $x$ Faktor Pengencer

\section{Pemurnian BAL}

Masing-masing koloni BAL yang spesifik digores berkali-kali ke media de Man Rogosa Sharpe Agar (MRSA) sehingga diperoleh koloni yang murni. Untuk koloni yang sudah murni, dibuat kultur kerja dan kultur stock. Kultur (isolat) stok dapat disimpan selama 3 bulan pada suhu $5^{\circ} \mathrm{C}$.

\section{Pengujian Diameter Zona Bening E. coli}

Bakteri uji yang digunakan adalah $E$. coli. E. coli terlebih dahulu ditumbuhkan menggunakan media Nutrient Agar (NA) dan diinkubasi selama 24 jam pada suhu ruang (Cintas et al., 1995). Prosedur pengujian diameter zona bening dapat dilihat pada Gambar 2 .

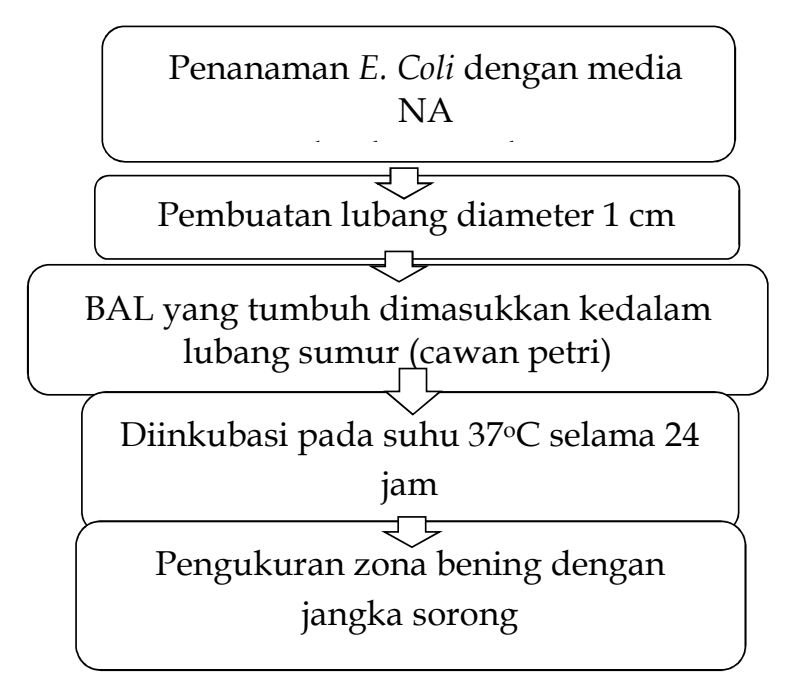

Gambar 2. Pengujian Diamater Zona Bening

\section{HASIL DAN PEMBAHASAN}

Rataan $\mathrm{pH}$ silase limbah jagung dengan penambahan tepung jagung yang berbeda dapat dilihat pada Tabel 1 .

Berdasarkan Tabel 1, tidak terjadi interaksi antara jenis bahan dengan penambahan tepung jagung yang berbeda $(\mathrm{P}>0,01)$ dalam menurunkan $\mathrm{pH}$. Faktor jenis bahan yang digunakan berpengaruh sangat nyata $(\mathrm{P}<0,01)$, dilihat dari hasil penelitian memperlihatkan bahwa $\mathrm{pH}$ yang baik terdapat pada perlakuan A1 $(100 \%$ Kulit Buah Jagung $+0 \%$ Jerami Jagung). Hal ini disebabkan karena kecukupan substrat karbohidrat larut air pada perlakuan (A1) sangat baik sehingga berpengaruh terhadap peningkatan pemanfaatan substrat oleh bakteri asam laktat yang berimplikasi terhadap penurunan $\mathrm{pH}$. Hal ini sesuai dengan pernyataan Cherney et al. (2004) yang menyatakan bahwa kandungan karbohidrat terlarut berhubungan positif dengan nilai $\mathrm{pH}$ silase. Karbohidrat larut 
air (WSC) akan dimanfaatkan oleh bakteri asam laktat untuk memproduksi asam

dan menurunkan $\mathrm{pH}$ (Chen and Wienberg, 2008).

Tabel 1. Rataan pH Silase Limbah Jagung dengan Penambahan Level Tepung Jagung

\begin{tabular}{|c|c|c|c|c|}
\hline \multirow{2}{*}{ Jenis Bahan } & \multicolumn{3}{|c|}{ Penambahan Tepung Jagung } & \multirow{2}{*}{ Rataan } \\
\hline & B1 & B2 & B3 & \\
\hline A1 & $3,38 \pm 0,07$ & $3,42 \pm 0,05$ & $3,37 \pm 0,02$ & $3,39 \pm 0,02^{a}$ \\
\hline A2 & $3,39 \pm 0,02$ & $3,87 \pm 0,16$ & $3,65 \pm 0,05$ & $3,81 \pm 0,02^{a b}$ \\
\hline A3 & $4,12 \pm 0,64$ & $4,22 \pm 0,57$ & $4,24 \pm 0,88$ & $4,19 \pm 0,06^{b}$ \\
\hline Rataan & $3,81 \pm 0,39$ & $3,83 \pm 0,40$ & $3,75 \pm 0,45$ & \\
\hline
\end{tabular}

Keterangan : Hasil analisis Laboratorium Patologi, Entomologi dan Mikrobiologi UIN Suska Riau (2017)

A1 $=100 \%$ Kulit Buah Jagung + 0\% Jerami Jagung, A2 $=50 \%$ Kulit Buah Jagung $+50 \%$ Jerami Jagung, $A 3=0 \%$ Kulit Buah Jagung $+100 \%$ Jerami Jagung. B1= $\%$, B2= 5\%, B3= $10 \%$.

Superskrip huruf yang berbeda pada kolom (huruf kecil) yang sama menunjukkan pengaruh yang sangat nyata $(\mathrm{P}<0,01)$

Penambahan tepung jagung yang berbeda tidak berpengaruh nyata $(\mathrm{P}>0,01)$ terhadap $\mathrm{pH}$ silase limbah jagung kemungkinan disebabkan substrat karbohidrat larut air sudah mencukupi pada silase limbah jagung sehingga tidak memperlihatkan pengaruh penambahan tepung jagung terhadap penurunan $\mathrm{pH}$. Hal ini sesuai dengan pendapat Nusio (2005) yang menyatakan apabila seluruh bagian tanaman jagung dibuat silase, maka karbohidrat larut air yang dibutuhkan untuk pertumbuhan bakteri sudah mencukupi.

Rataan $\mathrm{pH}$ yang dihasilkan adalah 3,80 lebih rendah dibandingkan dengan penelitian Gurning (2013) yang menyatakan $\mathrm{pH}$ jus silase jagung yang dihasilkan berkisar antara 3,87.

\section{Populasi Bakteri Asam Laktat}

Rataan populasi BAL silase limbah jagung dapat dilihat pada Tabel 2 .

Tabel 2. Rataan Populasi BAL pada Silase Limbah Jagung $\left(\log _{10} \mathrm{cfu} / \mathrm{ml}\right)$

\begin{tabular}{ccccc}
\hline \multirow{2}{*}{ Jenis Bahan } & \multicolumn{3}{c}{ Penambahan Tepung Jagung } & \multirow{2}{*}{ Rataan } \\
\cline { 2 - 4 } & B1 & B2 & B3 & \\
\hline A1 & $7,33 \pm 0,15$ & $7,14 \pm 0,14$ & $7,35 \pm 0,08$ & $7,27 \pm 0,02^{\mathrm{a}}$ \\
A2 & $7,37 \pm 0,14$ & $7,43 \pm 0,07$ & $7,40 \pm 0,04$ & $7,40 \pm 0,02^{\mathrm{b}}$ \\
A3 & $7,50 \pm 0,20$ & $7,43 \pm 0,06$ & $7,29 \pm 0,09$ & $7,41 \pm 0,06^{\mathrm{b}}$ \\
\hline Rataan & $7,40 \pm 0,39$ & $7,33 \pm 0,40$ & $7,35 \pm 0,45$ & \\
\hline
\end{tabular}

Keterangan : Hasil analisa Laboratorium Patologi, Entomologi dan Mikrobiologi UIN Suska Riau (2017)

A1 $=100 \%$ Kulit Buah Jagung + 0\% Jerami Jagung, A2 $=50 \%$ Kulit Buah Jagung $+50 \%$ Jerami Jagung, A3=0\% Kulit Buah Jagung $+100 \%$ Jerami Jagung. B1= 0\%, B2= 5\%, B3= $10 \%$.

Superskrip huruf yang berbeda pada kolom (huruf kecil) yang sama menunjukk an pengaruh yang sangat nyata $(\mathrm{P}<0,01$

Tidak terjadinya interaksi antara faktor jenis bahan dengan penambahan tepung jagung yang berbeda tidak berpengaruh nyata $(\mathrm{P}>0,01)$ terhadap populasi bakteri asam laktat
Faktor jenis bahan silase berpengaruh berbeda nyata $(\mathrm{P}<0,05)$ pada perlakuan A1 ( 100\% Kulit Bah Jagung + 0\% Jerami Jagung) terlihat populasi bakteri asam laktat nyata lebih rendah dibandingkan pada A2 dan A3. Hal ini kemungkinan 
disebabkan adanya perbedaan bahan silase yang digunakan, dimana bakteri asam laktat lebih dominan pada daun dibandingkan pada kulit. Sesuai dengan pernyataan McDonald et al. (1991) mengemukakan bahwa bakteri asam laktat merupakan suatu group bakteri yang dapat menghasilkan asam laktat dan selalu ditemukan pada hijauan, terutama pada bagian permukaan daun.

Penambahan tepung jagung yang berbeda tidak berpengaruh nyata $(P>0,01)$ terhadap populasi bakteri asam laktat kemungkinan disebabkan faktor jenis bahan silase yang digunakan sudah mencukupi tanpa ada penambahan bahan additif lainnya sebagai sumber energi. Sesuai dengan pernyataan Muck (1990) bahwa populasi BAL secara alami sudah terdapat pada hijauan tropis tetapi tergantung pada spesies tanaman. Didukung pendapat Nusio (2005) yang menyatakan apabila seluruh bagian tanaman jagung dibuat silase, maka karbohidrat terlarut yang dibutuhkan untuk pertumbuhan bakteri sudah mencukupi. Kuswandi (1993) menyatakan mikrobia pada umumnya menggunakan bermacam-macam karbohidrat sebagai sumber utama energi baik dalam bentuk polisakarida, disakarida maupun monosakarida.

Hasil penelitian ini lebih rendah dibandingkan dengan penelitian Gurning (2013) jus silase jagung menghasilkan jumlah populasi BAL 10,32 $\pm 9,84 \mathrm{cfu} / \mathrm{ml}$ tetapi lebih tinggi dari penelitian Lendrawati (2012) jumlah koloni bakteri asam laktat isolat silase ransum komplit jagung yaitu 9,2 $\times 10^{5} \mathrm{cfu} / \mathrm{g}$, dan Harahap (2011) jumlah koloni bakteri asam laktat isolat silase ransum komplit jagung yaitu $6,05 \times 10^{6} \mathrm{cfu} / \mathrm{g}$.

\section{Diameter Zona Bening}

Rataan diameter zona bening BAL terhadap E. coli dari silase jagung dengan penambahan tepung jagung yang berbeda dapat dilihat pada Tabel 3.

Tabel 3. Rataan Zona Bening (cm) BAL terhadap E. coli dari Silase jagung dengan Penambahan Berbagai Level Tepung Jagung.

\begin{tabular}{|c|c|c|c|c|}
\hline \multirow{2}{*}{ Jenis Bahan } & \multicolumn{3}{|c|}{ Penambahan Tepung Jagung } & \multirow{2}{*}{ Rataan } \\
\hline & B1 & B2 & B3 & \\
\hline A1 & $0,62 \pm 0,13$ & $0,69 \pm 0,17$ & $0,78 \pm 0,39$ & $0,70 \pm 0,14^{a}$ \\
\hline $\mathrm{A} 2$ & $0,63 \pm 0,23$ & $1,09 \pm 0,13$ & $1,02 \pm 0,28$ & $0,91 \pm 0,13 \mathrm{ab}$ \\
\hline A3 & $1,05 \pm 0,13$ & $1,23 \pm 0,26$ & $1,06 \pm 0,22$ & $1,11 \pm 0,07 b$ \\
\hline Rataan & $0,77 \pm 0,39$ & $1,00 \pm 0,40$ & $0,95 \pm 0,45$ & \\
\hline
\end{tabular}

Keterangan : Hasil analisa Laboratorium Patologi, Entomologi dan Mikrobiologi UIN Suska Riau (2017)

A1 $=100 \%$ Kulit Buah Jagung + 0\% Jerami Jagung, A2= 50\% Kulit Buah Jagung + 50\% Jerami Jagung, A3=0\% Kulit Buah Jagung $+100 \%$ Jerami Jagung. B1 $=0 \%$, B2= 5\%, B3= $10 \%$.

Superskrip huruf yang berbeda pada kolom (huruf kecil) dan yang sama menunjukkan pengaruh yang

sangat nyata

$(\mathrm{P}<0,01)$

Tidak terjadinya interaksi antara faktor jenis bahan dengan penambahan tepung jagung yang berbeda $(\mathrm{P}<0,01)$ terhadap diameter zona bening $\mathrm{BAL}$ terhadap E. coli. Faktor jenis bahan yang digunakan berpengaruh sangat nyata $(\mathrm{P}<0,01)$ terhadap diameter zona bening terhadap E. coli. Hal ini kemungkinan disebabkan bakteri asam laktat silase jagung ini didominasi oleh bakteri asam laktat tipe heterofermentatif yang produk fermentasinya selain menghasilkan asam laktat juga menghasilkan asam asetat dan asam propionat. Kombinasi asam-asam tersebut memiliki kemampuan untuk 
menekan kerja bakteri patogen lebih baik dibandingkan dengan satu jenis asam saja. Axelsson (1998) menyatakan kombinasi asam laktat, asetat dan propionat mampu menekan kerja bakteri patogen yang diindikasikan dengan semakin besarnya daya hambat yang dihasilkan. Alakomi et al. (2000) menambahkan membran lapisan luar bakteri gram negatif akan rusak oleh kombinasi asam yang dihasilkan BAL.

Penambahan tepung jagung yang berbeda tidak berpengaruh nyata $(P>0,05)$ terhadap diameter zona bening $\mathrm{BAL}$ terhadap E. coli diduga karena pada bahan silase yang telah digunakan sudah mencukupi sehingga tidak diperlukan bahan aditif lainnya. Sesuai yang disampaikan dengan Salminen et al. (1998) bahwa asam laktat terbentuk dari bahan baku karbohidrat mudah larut, melalui proses enzimatis oleh enzim komplek yang terbentuk oleh bakteri asam laktat. Hal ini didukung oleh Yang (2000) menyebutkan bakteri asam laktat menghasilkan berbagai komponen antibakteri lainnya seperti hidrogen peroksida $\left(\mathrm{H}_{2} \mathrm{O}_{2}\right)$, karbondioksida $\left(\mathrm{CO}_{2}\right)$, diasetil dan bakteriosin.

Hasil penelitian ini memiliki rataan diameter zona bening $0,91 \mathrm{~cm}$ lebih tinggi dibandingkan dengan penelitian Harahap (2011) yang menyatakan bahwa Bakteri asam laktat asal isolat jagung memiliki diameter zona bening terhadap E. coli ayam yaitu 0,38 cm dan Gurning (2013) menyatakan diameter zona bening jus silase terhadap E.coli berkisar antara 0,30 $\mathrm{cm}$.

\section{KESIMPULAN}

\section{Kesimpulan}

1. Tidak terdapat interaksi antara faktor jenis bahan yang berbeda dengan penambahan tepung jagung terhadap $\mathrm{pH}$, jumlah populasi bakteri asam laktat, dan zona bening BAL terhadap E. coli.
2. Perlakuan silase dengan penambahan jerami jagung $100 \%$ merupakan perlakuan terbaik karena dapat menurunkan $\mathrm{pH}$, meningkatkan jumlah populasi BAL dan diameter zona bening

\section{Saran}

1. Tidak perlu adanya penambahan tepung jagung dalam pembuatan silase berbahan limbah jagung.

2. Perlu pengujian lebih lanjut tentang identifikasi dari bakteri asam laktat yang dihasilkan pada silase kulit buah dan jerami jagung dengan penambahan tepung jagung yang berbeda.

\section{DAFTAR PUSTAKA}

Alakomi H.L., E. Skyttä , M. Saarela, S.T. Mattila, K.T. Latva and I.M. Helander. 2000. Lactic acid permeabilizes gramnegative bacteria by disrupting the outer membrane. Appl Environ Microbiol. 66 : 2001-2005.

Axelsson L. 1998. Lactic acid bacteria: Classification and physiology. Di dalam:Salminen S, Wright and A Von Wright, Editor. Lactic Acid Bacteria: Microbiology and functional aspects, 2nd Edition, Revised and Expanded. Marcel Dekker Inc. pp 1-72. New York.

Badan Pusat Statistika (BPS), 2015. Riau Dalam Angka. Badan Pusat Statistika Provinsi Riau. Pekanbaru.

Buckmaster, D. 1992. Bacterial Inoculants for Silage. http//www.ege.psu.edu/ extension/factsheets/i/I111.pdf. Diakses pada tanggal 20 Desember 2016.

Cappucino, J.G., and N. Sherman. 2005. Microbiology a Laboratory Manual. $7^{\text {Th }}$ Edition. Pearson Education, Inc. San Francisco. USA.

Chelule, P. K., Mokoena, M.P. dan N. Galeni. 2010. Advantages of traditional lactid acid bacteria fermentation of food in Africa. Current Research, Technology and Education Topics in Applied 
Microbiology and Mikrobial Biothecnology, 2: 1160-1167.

Cherney, D.J.R., J.H. Cherney and W.J. Cox. 2004. Fermentation characteristics of corn forage ensiled in mini silos. J. Dairy Sci. 87:4238-4246.

Chen, Y. and Z. G. Weinberg. 2008. Changes during aerobic exposure of wheat silages. Anim. Feed Sci and Tech. 154:76-82.

Cintas, L.M., Rodriguez J.M., Fernandes M.F., Sletten K., Nes I.F., Hernandez P.E., and Holo H., 1995. Isolation and characterization of Pediocin L50, a new bacteriocin from Pediococus acidlactic with a broad inhibitory spectrum. Appl and Envir Microbiology. 61 (7) : 26432648.

Dwidjoseputro, D. 2005. Dasar-dasar Mikrobiologi. Djambatan. Jakarta. hal. 214.

Gurning, F. N. 2013. Profil jus silase jagung dan kemampuannya dalam menghambat Escherichia coli dan Salmonella sp. yang diisolasi dari feses pedet diare. Sekolah Pascasarjana. Laporan Penelitian. Institut Pertanian Bogor. Bogor.

Harahap, A. E. 2011. Kajian daya hambat bakteri asam laktat silase ransum komplit berbasis hasil samping jagung, ubi kayu dan sawit. Jurnal Peternakan. 8 (2) : 44-48.

Kuswandi, 1993. kegiatan mikroba di rumen dan manipulasinya untuk menaikkan efisiensi produksi ternak. Buletin Peternakan 17. 68-76.

Lendrawati, M. Ridla dan N. Ramli. 2012. Kualitas fermentasi silase ransum komplit berbasis jagung, sawit dan ubi kayu. Jurnal Peternakan Indonesia. 14 (1) : 297302.

Macaulay, A. 2004. Evaluating Silage Quality.http://www1.agric.gou.ab.ac/de partment/deptdocs.nsf/all/for4009.html (Desember 2016).

McDonald P, A.R. Henderson, dan S.J.E. Heron. 1991. The Biochemistry of Silage.
Second Edition. Aberystwyth (GB) : J Wiley.

Muck, R. E. 1990. prediction of lactic acid bacteria numbers on lucerne. Grass Forage Sci. 45:273-280.

Mugiawati, R. E. 2013. Kadar air dan pH silase rumput gajah pada hari ke-21 dengan penambahan jenis aditif dan bakteri asam laktat. Jurnal Ternak Ilmiah. 1 (1): 201-207.

Nusio, L. G. 2005. Silage Production from Tropical Forages. In: Silage Production and Utilization. Park, R.S. and M.D. Stronge(Eds.). Wageningen Academic Publ., the Netherlands. Pp. 97-107.

Salminen, S., and Atte van W, 1998. Lactic Acid Bacteria Microbiology and Funcional aspect $2^{\text {nd }}$ Ed. Marcel Dekker, Inc. New York. Basel.

Sibanda, S. R., M. Jingura, and J. H. Topps. 1997. The effect of level of inclusion of the legume Desmodium uncinatum and the use of molasses or ground maize as additives on the chemical composition of grass-and maize-legume silages. Anim feed Sci. Technol. 68:295-305.

Sudarmadji, S., H. Bambang dan Suhardi. 1997. Prosedur Analisa untuk Bahan Makanan dan Pertanian. Penerbit Angkasa. Bandung.

Theurer, C.B., J.T. Huber, A. DelgardoElorduy, and . R. Wanderley. 1999. Invited Review : summary of steam flaking corn or shorgum grain for lactating dairy cows. Journal of Dairy Science 82. 1950-1959.

Umam, S., N. P. Indriani dan A. Budiman. 2014. Pengaruh Tingkat Penggunaan Tepung Jagung sebagai Aditif pada Silase Rumput Gajah (Pennisetum purpureum) terhadap Asam Laktat, $\mathrm{NH}_{3}$ dan $\mathrm{pH}$. Fakultas Peternakan Universitas Padjajaran. Bandung.

Yang, C., M.J., S.C. Huang, T. Chang, Y.H. Cheng, and C.T. Chang. 2004. fermentation acids, aerobic fungal growth, and intake of napier grass ensiled 
with non fiber carbohidrates. Journal Dairy Sci, 87 : 630-636. 